Jurnal Pemikiran Sosiologi Volume 6 No. 1, Januari 2019

\title{
Wisata Halal dan Identitas Islami: Studi Kasus Lombok, Nusa Tenggara Barat ${ }^{1}$
}

\author{
Mohammad Jeffry Maulidi2
}

\begin{abstract}
Abstraksi
Penelitian ini merupakan studi kasus penelitian lapangan yang menggunakan metode kualitatif dengan pendekatan sejarah dan sosiologis. Subyek penelitian ini adalah masyarakat pelaku pariwisata di Kawasan Ekonomi Khusus di pulau Lombok, Nusa Tenggara Barat (NTB). Penelitian dilakukan untuk melihat sejauhmana implementasi syariah Islam melalui wisata halal berkontribusi pada kondisi masyarakat lokal di pulau Lombok, NTB. Orientasi perubahan sosial masyarakat melalui formalisasi identitas Islam dianggap sebagai wujud kebijakan lokal untuk pembangunan sumberdaya manusia. Pemerintah lokal dan didukung oleh pemerintah pusat mewujudkannya dengan pembangunan 'Daerah Kawasan Ekonomi Khusus' (KEK). Kesimpulan penelitian ini menjelaskan bahwa implementasi pembangunan Daerah Kawasan Ekonomi Khusus (KEK) lebih mendatangkan keuntungan bagi kepentingan yang bersifat pro bisnis ketimbang pemberdayaan bagi masyarakat di Lombok yang relijius.
\end{abstract}

Kata kunci: wisata halal, identitas Islami, Daerah Ekonomi Khusus, Lombok-NTB

\begin{abstract}
This research is a case study of field research that employs qualitative method with historical and sociological approaches. The subjects of this study are tourism actors in the Special Economic Zones in Lombok island, West Nusa Tenggara (NTB). The research is conducted to examine the implementation of halal tourism and its impactd to the local people in Lombok, NTB. The context of social changes in Lombok shows a tendency where local people begin to embrace formalization of Islamic identity and is considered by the government as a form of local wisdom for supporting human development. As a response, local government and supported by the central government initiate the development of 'Special Economic Zones' (SEZs). The study summarizes that the interpretation of Islamic sharia through the development of Special Economic Zone Regions (SEZs) only benefiting pro-business interests rather than empowering local religious people in Lombok island.
\end{abstract}

Keywords: halal tours, Islamic identity, Special Economic Zones, Lombok island - West Nusa Tenggara

\section{A. Latar Belakang}

Lombok sebagai destinasi wisata menawarkan keindahan alam melalui jalur pantai yang panjang yang identik dengan pasir putihnya sehingga para turis dapat memanjakan diri dengan berjemur atau bersantai. Destinasi di pulau-pulau kecil di sekitar pulau Lombok, yakni diantaranya Gili Trawangan, Gili Meno, Gili Air dan Gili Kondo telah lama dikenal wisatawan mancanegara (asing). Destinasi lainnya adalah kesejukan alam pegunungan di Pulau Lombok yang dilengkapi dengan air terjun yang menambah wisata yang tidak ada habis-habisnya. Memanjakan mata dengan pantai yang tak berujung, membawa kesejukan dengan bermain di bawah air terjun. pulau Lombok kini menjadi salah salah satu ikon pariwisata halal di Indonesia. Di satu sisi hal ini menjadi kebanggaan dan rasa syukur dari masyarakat Pulau Lombok.

Tujuan pendirian wisata halal di Lombok bagi pemerintah setempat adalah untuk meningkatkan nilai budaya dengan identitas Islami yang dianggap sebagai wujud kearifan lokal melalui

\footnotetext{
${ }^{1}$ Untuk kutipan atau sitasi artikel ini: Maulidi, Mohammad Jeffry. 2019. "Wisata Halal dan Identitas Islami: Studi Kasus Lombok, Nusa Tenggara Barat.” Jurnal Pemikiran Sosiologi Vol 6 (1): 18-26.

${ }^{2}$ Program Pascasarjana (S3) Universitas Islam Negeri Mataram. Kontak penulis: mohammadjeffry1@gmail.com
} 
Jurnal Pemikiran Sosiologi Volume 6 No.1 2019

Wisata Halal dan Identitas Islami: Studi Kasus Lombok, Nusa Tenggara Barat

Mohammad Jeffry Maulidi

pembangunan Daerah Kawasan Ekonomi khusus (KEK). Secara ideal kebijakan ini dianggap dapat ikut mempercepat pencapaian pembangunan ekonomi nasional dengan mempercepat perkembangan daerah dan sebagai model "terobosan" pengembangan kawasan untuk pertumbuhan ekonomi, khususnya pariwisata yang pelaksanaannya bersesuaian dengan nilai dan norma warga setempat khususnya kecenderungan masyarakat setempat untuk mempraktikkan syariah Islam. Pengembangan pariwisata halal secara ideal juga ditujukan untuk mewujudkan masyarakat NTB yang beriman, berbudaya, berdaya saing dan sejahtera, menjadi arah pemerintah daerah dalam menetapkan langkah pembangunan daerahnya. "Beriman" oleh masyarakat setempat dimaknai dengan masyarakat yang agamis (Islami), yang melaksanakan ajaran agama dengan baik, berakhlak mulia dan saling menghargai satu sama lain.

Secara etimologis, kata "wisata" berarti bepergian bersama-sama (untuk memperluas pengetahuan, bersenang-senang, dan sebagainya); perjalanan yang memanfaatkan potensi sumber daya alam dan tata lingkungannya sebagai objek tujuan wisata; berlibur atau hanya ingin menikmati keindahan alam. Sedangkan kata "halal" adalah istilah yang sangat erat dengan relasi kehidupan orang-orang Islam (Muslim) yaitu segala objek atau kegiatan yang diizinkan untuk digunakan atau dilaksanakan, dalam ajaran Islam sesuai kitab suci umat Islam. Relasi kata "halal", memiliki makna yang sangat beragam, diantaranya dalam hal makanan, mencari nafkah, dan lain sebagainya. Secara struktur bahasa kedua kata tersebut berada pada relasi yang sangat timpang secara struktur pemaknaan, tetapi jika disandingkan menjadi bentuk padanan kata maka akan terdapat keterkaitan yang saling memberikan makna yang kuat dimana aktivitas ekonomi juga merupakan bagian dari pembangunan karakter identitas manusia yang Islami.

Islam sebagai agama yang rahmatan lil alamin secara sosial menempatkan upaya untuk menjaga perilaku dan hubungan baik antar sesama manusia (hablum minannas) terutama dalam menjaga persatuan dan persaudaraan. Dalam bidang muamalah hubungan sesamanya, umat Islam secara ideal diharuskan untuk menghargai berbagai kearifan lokal yang tidak melanggar syariat Islam dan wajib meluruskannya manakala bertentangan dengan syariat Islam, sehingga kearifan lokal dimaknai sebagai bentuk ketaatan pada aturan Allah SWT. Oleh karena itu, dalam pewacanaannya, karakter identitas Islami perlu melibatkan para penggerak mubaligh dan cendekiawan muslim agar tercipta kesederhanaan pemahanan ilmu pembelajaran Islam.

Berkenaan dengan dampak pariwisata di Pulau Lombok yang dianggap kurang menghargai aspek nilai masyarakat lokal yang kini banyak dipengaruhi oleh nilai-nilai Islam, upaya untuk mengembangkan wisata halal menjadi salah satu tujuan yang bukan hanya diminati oleh pemerintah semata. Upaya itu dilakukan pula dengan pengembangan pendidikan identitas Islami bagi para kader dakwah, mubaligh, aparatur setempat sehingga diharapkan dapat mempengaruhi pelaku ekonomi yang dapat menerapkan praktik nilai keIslaman yang lebih syar'i dan bersesuaian dengan budaya masyarakat di pulau Lombok dalam 
Jurnal Pemikiran Sosiologi Volume 6 No.1 2019

Wisata Halal dan Identitas Islami: Studi Kasus Lombok, Nusa Tenggara Barat

Mohammad Jeffry Maulidi

mengembangkan pariwisata. Selain itu, meningkatnya permintaan pasar untuk wisata halal juga menjadi alasan bagi pembangunan Zona Ekonomi Khusus melalui wisata halal.

\section{B. Metode Penelitian dan Kerangka Analisis Modernisasi Islam}

Penelitian ini merupakan studi kasus dengan menggunakan pendekatan kualitatif. Pendekatan ini juga menggunakan rujukan literatur sejarah dan analisis sosiologis yang mengkaitkan aspek perubahan sosial dan interpretasi atas nilai-nilai budaya Islam. Keterkaitannya dapat dijelaskan melalui sejarah perkembangan masyarakat dan bagaimana modernisasi Islam melalui pendidikan dianggap sebagai sesuatu yang tidak terpisahkan dari perkembangan masyarakat moderen. Dengan kata lain, pembaharuan pendidikan merupakan pintu masuk bagi pengembangan nilai dan norma yang berlangsung di masyarakat.

Pembaharuan pendidikan dan dampaknya pada modernisasi tidak semata timbul dengan sendiri tapi memerlukan proses perkembangan di dalam masyarakat. Di Indonesia salah satunya dalam sejarah adalah melalui politik etis dimana modernisasi pendidikan di Indonesia berlangsung pada awalnya. Aspek-apsek pembaharuan yang menjadi sasaran perbaikan adalah bidang pendidikan. Sebenarnya sebelum tahun 1901 pemerintah kolonial telah mendirikan beberapa sekolah untuk penduduk Bumiputera, untuk menyediakan tenaga pengajar. Pada tahun 1875 di Bandung didirikan sebuah sekolah guru, sebelumnya pada tahun 1851 di Batavia didirikan Sekolah Dokter Jawa (Bani, 2013: 5). Di dalam konteks ini sebenarnya juga berlangsung persebaran misi kristenisasi, selain upaya membantu memperbaiki kehidupan rakyat di masa kolonial. Jadi modernisasi pendidikan acapkali berkenaan pula dengan modernisasi identitas keagamaan suatu masyarakat. Dalam sejarahnya, pelaksanaannya politik etis di masa kolonial berdampak pada jumlah anggota masyarakat yang dampak bersekolah walaupun sampai tingkat pendidikan dasar. Meski demikian, justru melalui pendidikanlah rakyat bisa melawan penjajah dan memulai proses modernisasinya sendiri dengan cara pembelajaran dan tempat pelaksanaan kegiatan belajar mengajar seperti mengenal seragam, meja, kursi dan papan tulis, dan lain sebagainya. Sementara, perkembangan Islam di masa kolonial lebih banyak didasari dengan semangat persaudaraan walaupun saat itu masih secara tradisional seperti halaqoh atau tatap muka di masjid.

Berkenaan dengan modernisasi Islam, sebenarnya pelekatan identitas Islami dapat bersesuaian dengan perkembangan masyarakat moderen termasuk dalam kegiatan produktif masyarakat. Dalam bukunya "Islam dan Sains Modern: Bagaimana mempertemukan Islam dengan Sains Moderen", Nidhal Guessoum (2011) mengawali pemikirannya terkait gagasan integrasi sains dengan landasan tauhid (konsep tentang Tuhan) dan al-Qur'an sebagai pendekatan filsafat sainsnya. Konsep keTuhanan menjadi landasan pertama Geussoum dalam membahas integrasi sains dan Islam. Sebab tak ada prinsip yang lebih utama dan sentral dalam Islam selain konsep tentang Tuhan, dan tidak ada tata aturan yang lebih 
Jurnal Pemikiran Sosiologi Volume 6 No.1 2019

Wisata Halal dan Identitas Islami: Studi Kasus Lombok, Nusa Tenggara Barat

Mohammad Jeffry Maulidi

fundamental dalam bangunan Islam selain alQur'an. Oleh karena itu, Nidhal Guessoum (2011) merekomendasikan pentingnya membangun jembatan komunikasi dan jejaring antar peneliti. Jaringan peneliti Muslim dengan kolega-koleganya di Eropa, Amerika dan belahan dunia lainnya, menjadi upaya penting dalam memahami identitas Islami yang bersifat moderen. Ajaran Islam dan sains tidak saling menegasikan, sebagaimana diwariskan Ibnu Rushd, Ibnu Sina dan beberapa ilmuwan Muslim. Justru ilmuan Muslim masa kini harus membangun jembatan yang lebih kokoh, bagaimana nilai-nilai Islam mampu memberi sumbangsih bagi teknologi pada penguatan menguatkan peradaban seperti yang bisa dipraktikkan pada aktivitas ekonomi wisata halal.

Kalam, Falsafah, Fikih dan Dakwah Sosial modern tidak menolak keterlibatan sains (fisika, kimia, biologi, dan lain-lain). Juga tidak menolak keterlibatan ilmu-ilmu sosial (sosiologi, antropologi, psikologi, sejarah dan lain-lain) dan humanitas kontemporer isu-isu kemanusiaan universal seperti hukum dan HAM, keadilan Gender, hak-hak anak, family planning (tanzim al-nasl), dialog antar agama dan budaya, kekerasan yang mengatasnamakan agama, perubahan dalam membentuk cara pandang baru keagamaan dan keilmuan (aqidah), pola komunikasi dan tata pergaulan antar sesama (mu'amalah) dan perilaku hidup sehari-hari dalam kehidupan pribadi, keluarga dan masyarakat (akhlak) keagamaaan Islam (Amin Abdullah, 2014: 97-117). Banyaknya berbagai macam keilmuan dalam experimental sciences bisa memaksimalkan perkembangan perilaku setiap individu masyarakat, semua orang dianggap baik tergantung takaran ilmu yang dia miliki, sangat bermanfaat jika takaran ilmu itu datang dari cendekiawan muslim dan para mubaligh dimana ilmu yang dibagikan sesuai dan tidak bertentangan dan tidak menambah ataupun mengurangi isi yang sebenarnya dan tetap dalam modernisasi Islam.

\section{Implementasi Wisata Halal dan Pembangunan Zona Ekonomi Khusus di Lombok}

Berkenaan dengan implementasi wisata halal dan pembangunan sumberdaya manusia melalui nilai-nilai lokal (identitas Islami), pemerintah telah menetapkan Mandalika Resort sebagai Kawasan Ekonomi Khusus (KEK) lewat Peraturan Pemerintah (PP) Nomor 52 Tahun 2014 yaitu mengembangkan kawasan wisata seluas 1.175 hektar. Pengembangan Kawasan Mandalika sebenarnya sudah dimulai di era Orde Baru dari tahun 1987. Setelah beberapa tahun karena krisis moneter dan berbagai alasan lainnya, pada tahun 2011 akhir, Presiden Republik Indonesia saat itu Susilo Bambang Yudhyono meresmikan dimulainya masterplan pembangunan kawasan Mandalika Resort. Namun lagi-lagi pembangunannya mengalami banyak hambatan sehingga dilanjutkan lagi di era pemerintahan Jokowi. Mandalika Resort ditangani langsung oleh ITDC (Indonesia Tourism Development Corporation), salah satu BUMN Indonesia yang menyatakan bahwa Mandalika ini akan menjadi kawasan terpadu yang elit, eksklusif dan bertaraf internasional. Seperti Nusa Dua di Bali yang sukses dikembangkan ITDC sebelumnya.

Pembebasan lahan menjadi masalah utama dalam pengembangan kawasan ekonomi khusus 
Jurnal Pemikiran Sosiologi Volume 6 No.1 2019

Wisata Halal dan Identitas Islami: Studi Kasus Lombok, Nusa Tenggara Barat

Mohammad Jeffry Maulidi

(KEK) dan itu juga terjadi di kawasan Mandalika yang cukup lama berhenti beroperasi yang menjadikan lahan kawasan ekonomi khusus ini perlu di rekontruksi ulang. Lahan tanah KEK pun sudah dipergunakan kembali oleh masyarakat sekitar baik sebagai lahan pertanian maupun tempat tinggal. Proses pembebasan lahan dan rekontruksi ulang batas tanah kawasan Mandalika resort hampir rampung sebelum dilakukan peresmian langsung oleh Presiden Republik Indonesia, Joko Widodo pada tanggal 20 Oktober 2017. Dimulainya pembangunan infrastruktur dasar yang sudah dibangun antara lain akses jalan dalam kawasan, fasilitas pengolahan air bersih, masjid, pembangunan pagar kawasan, penataan ruang publik, dan sebagaianya.

Wujud dari rekontruksi lahan kawasan Mandalika berdampak pada mulai teraturnya proses pembangunan yang ada karena dari batas tanah yang hilang dan masih diragukan keberadaannya dan bisa ditentukan kembali dengan memasang tanda batas dan dilakukan pembangunan pagar batas kawasan. Selain rekontruksi lahan, upaya pembangunan Zona Kawasan Ekonomi Khusus juga memerlukan adanya rekontruksi sosial masyarakat sekitar kawasan. Hal ini diupayakan sebagai bagian dari pembangunan sumberdaya manusia yang memiliki pengetahuan sadar hukum dan tuntutan warga untuk pembangunan yang bersesuaian dengan norma dan nilai setempat khususnya di Kawasan Ekonomi Khusus di Mandalika Desa Kuta Kecamatan Pujut Kabupaten Lombok Tengah NTB.

Upaya pembangunan karakter identitas Islami bersumber dari al Quran dan Hadist melalui pendidikan Islam. Pendidikan Islam yang dimaksudkan disini adalah suatu proses bimbingan seorang pendidik terhadap perkembangan jasmani, rohani, dan akal peserta didik ke arah terbentuknya pribadi Muslim yang baik. Karena pendidikan islam merupakan alat yang dapat difungsikan untuk mengarahkan pertumbuhan dan perkembangan hidup manusia kepada titik optimal kemampuannya untuk memperoleh ketentraman hidup di dunia dan kebahagiaan hidup di akhirat. Dalam hal ini, pendidik berperan sebagai pemegang alat kunci yang banyak menentukan keberhasilan suatu proses pendidikan, sebagaimana telah berkembang di berbagai daerah dari sistem yang sangat sederhana sampai pada sistem pendidikan islam yang modern.

Rekontruksi sosial melalui pembentukan karakter budaya yang Islami bertujuan untuk memupuk, meramut, dan menciptakan generasi penerus yang bukan hanya dapat menjalankan kehidupan moderen, tetapi sekaligus dapat merepresentasikan identitas Islami yang dapat eksis dalam aktivitas yang bersifat multikultural, termasuk dalam kegiatan pariwisata. Karakter itu perlu diwujudkan dengan pembinaan yang menghasilkan sumber daya manusia yang unggul yang bisa menghadapi Pembangunan Kawasan Ekonomi khusus sebagai ikon pariwisata yang maju di pulau Lombok. Dengan kata lain, pengembangan karakter identitas Islami justru dapat mewakili pembangunan yang adil sekaligus memberikan contoh wajah Islam yang 'damai' dan umatnya mampu berinteraksi di dalam masyarakat dunia yang plural tanpa kehilangan jati dirinya sebagai Muslim. Bagi masyarakat setempat sendiri, pemahaman agama Islam dan pelekatan identitas Islami menjadi hal yang penting bagi 
Jurnal Pemikiran Sosiologi Volume 6 No.1 2019

Wisata Halal dan Identitas Islami: Studi Kasus Lombok, Nusa Tenggara Barat

Mohammad Jeffry Maulidi

keberlangsungan generasi. Bagi mereka, akal pikiran yang dinamis dan progresif yang dibangun melalui pendidikan karakter identitas Islami mempunyai peranan yang penting dalam pembentukan karakter yang baik. Budi pekerti menjadi sangat penting untuk penanaman nilai-nilai moral dan nilai-nilai sosial pada masyarakat pelaku industri pariwisata, karena pengaruh globalisasi membawa dampak menipisnya etika termasuk sopan santun dan diabaikannya tatanan masyarakat setempat hanya untuk mengejar keuntungan ekonomi semata-mata.

Upaya pemerintah daerah untuk menyelaraskan aspek pariwisata yang berkelanjutan dan upaya untuk penghormatan pada nilai-nilai lokal terutama yang berkenaan dengan identitas Islami, dilakukan pula dengan pendirian sekolah pariwisata. Hal ini dilakukan sebagai upaya untuk merekrut warga lokal untuk menyiapkan sumber daya manusia yang ada di sekitar KEK Mandalika. Walaupun masih minim tenaga pekerja untuk persiapan KEK Mandalika Pemerintah melalui Kementrian Pariwisa membuka perguruan tinggi Poltekkes Pariwisata yang sekarang masih dalam proses pembangunan di kawasan Praya Kabupaten Lombok Tengah yang bersebelahan dengan kampus IPDN Regional NTB. Hingga saat ini banyak investor asing maupun dalam negeri mulai melirik panorama dan keindahan pariwisata di Lombok yang sangat memikat dan dapat mengalahkan pamor pariwisata di daerah lain termasuk Bali sebagai ikon utama pariwisata Indonesia.

Para kapitalis yang mulai tertarik pada keberadaan lahan tanah di sekitar KEK Mandalika mulai merasakan adanya potensi besar memperoleh keuntungan dari investasi pariwisata. Mereka mulai memilih dan menjadikan wisata tersebut sebagai komoditas baru, yang dengannya akan meraup keuntungan yang tak terkira. Hal ini dilakukan dengan cara mengembangkan kegiatan yang lebih banyak bersandar pada aktivitas konsumsi khususnya bagi para turis, sehingga ikut mempengaruhi perilaku warga setempat. Perilaku dalam kegiatan konsumtif merupakan akumulasi dari konsumsi tanda dan simbol yang melekat pada terminologi pariwisata. Padahal hakikatnya, hanya berupa perwujudan simbol status, prestige, dan kepuasan akan bujuk rayu kapitalis dalam ikon-ikon pariwisata (Awalia, 2017: 19-30).

\section{Dampak Sosio-Kultural Wisata Halal bagi Masyarakat Lokal di Lombok}

Pulau Lombok dikenal dengan sebutan "pulau seribu Masjid" yang artinya bahwa di pulau Lombok sebagai tempat dimana islam sangat diterima dan dihormati. Penduduk Lombok atau disebut orang sasak yang mayoritas beragama islam dengan identitas orang sasak erat kaitannya sebagai seorang Muslim. Dimana akulturasi Islam dengan budaya lokal setempat berjalan dengan baik antara kultur budaya lokal dan islam saling menyatu. Disamping identitas Islam yang secara khusus ditunjukkan oleh masyarakat Lombok adalah praktik tradisi warisan nenek moyang yang dapat dijumpai di wilayah-wilayah destinasi wisata. Bentuk budaya lokal termasuk identitas Islami itu dapat ditemui di beragam destinasi wisata di pulau Lombok. Mulai dari hamparan pantai yang indah serta keadaan alam di pegunungan yang sejuk 
Jurnal Pemikiran Sosiologi Volume 6 No.1 2019

Wisata Halal dan Identitas Islami: Studi Kasus Lombok, Nusa Tenggara Barat

Mohammad Jeffry Maulidi

ditambah air terjun di sejumlah titik destinasi wisata seperti Air Terjun Sendang Gile dan Air Terjun Tiu Kelep yang termasuk pada wisata Geopark Rinjani. Mandalika adalah destinasi pariwisata kelas dunia di Indonesia yang merupakan Kawasan Ekonomi Khusus sebagai program prioritas dari pemerintah pusat. Destinasi wisata ini menawarkan beragam keindahan serta pengalaman unik yang berbeda dari tempat lainnya di seluruh dunia. Terletak di bagian selatan Pulau Lombok dengan hamparan pantai yang panjang lebih dari $16 \mathrm{~km}$ dengan pasir putih yang berkilau. Mandalika telah dirancang sebagai tujuan wisata ramah lingkungan (eco tourism), dengan menggabungkan clean solar cell energy, yakni bangunan desalinasi air dan menjaga lebih dari 51\% bagian dari resort sebagai ruang terbuka hijau. Dukungan infrastruktur penunjang seperti perpanjangan runway Bandara Internasional Lombok, revitalisasi Pelabuhan Lembar, serta penanganan jaringan air bersih kawasan Kuta dan sekitarnya, yang tidak hanya akan memelihara dan melindungi keindahan alam Mandalika, akan tetapi juga meningkatkan kehidupan dan budaya masyarakat setempat dan melestrikan kearifakan lokal yang juga mencerminkan budaya yang bersifat Islami.

Kawasan Ekonomi Khusus (KEK) Mandalika yang telah diresmikan oleh Presiden Republik Indonesia JokoWidodo dilaksanakan di Pantai Kute Desa Kuta Kecamatan Pujut Kawasan Mandalika Lombok Tengah pada hari Jumat tanggal 20 Oktober 2017. Kawasan ini dikelola oleh PT. Pengembangan Pariwisata Indonesia (Persero) atau Indonesia Tourism Development Corporation (ITDC). Peresmian Kawasan Ekonomi khusus ini setelah mangkrak selama 29 tahun, dalam peresmiannya mulai beroperasi dengan menerima investor dari 12 Kawasan Ekonomi Khusus yang ditetapkan pemerintah. Indonesia Tourism Development Corporation (ITDC) sebagai penanggung jawab pengembang kawasan ekonomi khusus Mandalika juga membangun masjid megah yang diberi nama 'Masjid Nurul Bilad' berukuran besar dengan kapasitas 1500 jamaah diatas lahan seluas 8 hektar (80.000m2), yang diklaim sebagai simbol peradaban Islam moderen di pulau Lombok. Sementara itu sebagian dari 1,5 hektar $(15.000 \mathrm{~m} 2)$ diantara pembangunan mesjid itu juga akan dibangun suatu zona perdagangan bagi para pelaku usaha mikro, kecil dan menengah (UMKM). Masjid Nurul Bilad sebagai simbol budaya Islam moderen yang ada di pulau Lombok dibangun dengan arsitektur yang memperlihatkan simbol budaya bangunan suku Sasak Lombok. Masjid Nurul Bilad ini juga menjadi bagian dari destinasi wisata halal yaitu wisata reliji Islam. Target pemerintah lokal adalah upaya untuk menjadikan mesjid sebagai destinasi wisata sekaligus sebagai tempat ibadah yang berkelas dunia. Jadi mesjid harus dibangun sebagai tempat ibadah yang nyaman dan berkelas dunia, seperti yang dicontohkan oleh Masjid Biru (Blue Mosque ) di Turki, misalnya. Padahal, di Lombok sendiri yaitu di pusat kota Mataram telah lama memiliki Islamic Center (IC) NTB menjadi tempat wisata yang banyak dikunjungi para wisatawan dan juga sebagai pusat pengkajian Islam di NTB.

Di Nusa Tenggara Barat sendiri khususnya di pulau Lombok memiliki keragaman suku, budaya, dan agama yang menjadi keunikan tersendiri di daerah ini. Dimana semua jenis suku dan agama 
Jurnal Pemikiran Sosiologi Volume 6 No.1 2019

Wisata Halal dan Identitas Islami: Studi Kasus Lombok, Nusa Tenggara Barat

Mohammad Jeffry Maulidi

hidup berdampingan satu sama lain. Daerah NTB dapat dikatakan sebagai daerah yang sangat jarang terjadi konflik agama ataupun suku. Walaupun beberapa waktu lalu terdengar konflik antar-agama ataupun suku yang terjadi akibat adanya gesekan kepentingan individu yang berujung pada konflik sosial. Secara keseluruhan, daerah ini termasuk kawasan yang tentram dan damai. Konsep wisata halal bisa dijalankan tanpa menimbulkan konflik sosial yang terjadi di masyarakat Lombok dengan tetap saling menghormati dan menghargai antar sesama manusia dan perbedaaan agama. Seperti ketika dilaksanakan kegiatan ibadah sholat jumat di masjid Jami' di wilayah Praya misalnya akan dijaga oleh anggota aparat kepolisian di lingkungan Polres Lombok Tengah yang beragama non muslim.

\section{E. Kesimpulan}

Meskipun dalam perkembangan sejarahnya, tidak banyak konflik sosial yang terjadi di wilayah Lombok, akan tetapi pembangunan pariwisata yang hanya mencari keuntungan dapat mengikis solidaritas warga setempat. Pembangunan wisata halal dengan pelekatan identitas Islami secara normatif bukan sesuatu yang ditentang masyarakat di NTB, bahkan oleh anggota masyarakat yang non Muslim. Akan tetapi, dalam perkembangannya, pelekatan identitas Islami itu hanya berwujud pada simbolisasi pembangunan mesjid dan destinasi wisata halal yang tidak atau belum banyak melibatkan masyarakat lokal setempat yang mayoritas adalah Muslim yang taat. Pendidikan multikulturalisme dalam pengembangan karakter identitas Islam termasuk di wilayah NTB perlu diwujudkan secepat mungkin dengan mempertimbangkan perkembangan perilaku sosial yang berkembang sebagai dampak dari kehidupan moderen yang terlalu kapitalis. Banyak peristiwa yang menunjukkan dampak dari ketidakharmonisan ini terjadi di Indonesia,yang kemudian bermuara pada perubahan suasana pergaulan khususnya generasi penerus dan tidak hanya gesekan secara psikis melainkan juga secara fisik, dan menimbulkan gejolak yang mempengaruhi pola pikir dalam memandang interaksi sosial dalam bermasyarakat ..

Paradigma pendidikan karakter Islami oleh karenanya perlu dikembangkan dan diorientasikan untuk membangun kesadaran intelektual untuk melihat berbagai realitas perbedaan sosial sebagai bentuk partisipasi kritis warga, sekaligus perbedaan kultural sebagai potensi kekuatan yang harus dihargai dan justru penting dipelihara. Di sisi lain, kurikulum pendidikan dengan berbagai komponen di dalamnya baik tujuan, proses,dan evaluasi akhir harus dikembangkan dalam konteks masyarakat dengan berbagai keragaaman budaya. Tempat pelaksanaan pendidikan tidak boleh menjadi institusi yang justru melemahkan pandangan sempit mengenai budaya dan realitas sosial. Dunia pendidikan wajib memperhatikan pertumbuhan pendidikan generasi penerus mulai dari anak-anak sampai remaja pada pembinaan karaktek daerah wisata yang ada di masyarakat Lombok.

Upaya mempraktikkan identitas budaya Islam melalui pembangunan Daerah Kawasan Ekonomi Khusus (KEK) merupakan kebijakan yang lebih menguntungkan kepentingan pro bisnis. "Wisata halal" yang menjadi ikon bagi masyarakat NTB belum sepenuhnya melibatkan partisipasi 
Jurnal Pemikiran Sosiologi Volume 6 No.1 2019

Wisata Halal dan Identitas Islami: Studi Kasus Lombok, Nusa Tenggara Barat

Mohammad Jeffry Maulidi

warga termasuk generasi muda di wilayah setempat. Mandalika sebagai destinasi pariwisata kelas dunia di Indonesia dan menjadi Kawasan Ekonomi Khusus juga merupakan program prioritas dari pemerintah pusat. Akan tetapi, dalam perkembangannya, konsep wisata halal belum juga terintegrasi dengan kegiatan yang telah lama dikelola oleh komunitas Muslim di Lombok. Hal ini dapat menimbulkan keresahan karena konsep wisata halal bisa dijalankan tanpa menimbulkan konflik sosial yang terjadi di masyarakat Lombok dengan tetap saling menghormati dan menghargai antar sesama manusia dan perbedaaan agama. Pemerintah dalam menghadapi pembangunan KEK Mandalika juga perlu melibatkan pakar pendidikan, guru, dan orang tua dalam kelancaran kegiatan mampu membimbing generasi penerus yang berdaya juang tinggi yang didasari pemahaman tentang agama Islam yang baik dan memiliki ketrampilan mengolah pariwisata moderen tanpa meninggalkan identitas budaya masyarakat setempat.

\section{Daftar Pustaka}

Amin Abdullah, Muhammad. 2013. "Agama, Ilmu dan Budaya: Paradigma IntegrasiInterkoneksi Keilmuan." Pidato Inaugurasi sebagai anggota Akademi Ilmu Pengetahuan Indonesia (AIPI), UGM, Yogyakarta,

2014 "Kontribusi Ilmu Kalam/Filsafat Islam dalam Pembangunan Karakter Bangsa." Ilmu Ushuluddin Vol 13 (2): $97-117$

Awalia, Hafizah. 2017. "Komodifikasi Pariwisata Halal NTB dalam Promosi Destinasi Wisata
Islami di Indonesia”. Jurnal Studi Komunikasi Vol 1 (1):19-30

Maufur, 2014. Islam dan Sains Modern. Bandung: PT Mizan Pusataka

Nidhal Guessoum, 2011. Islam's Quantum Question : Reconciling Muslim Tradition and Modern Science . London: I.B. Tauris and Co

Solikhudin, Muhammad. 2016. "Rekonsiliasi Tradisi Muslim dan Sains Modern Telaah atas Buku Islam's Quantum Question Karya Nidhl Guessoum. Kontemplasi: Jurnal Ilmu-Ilmu Ushulludin Vol 4 (2):403-422

Ritzer, George. Teori Sosiologi dari Klasik sampai Perkembangan Terakhir Posmodern. Yogyakarta: Pustaka Pelajar.

Suddin Bani. 2013. "Politik Etis", Jurnal Politik Profetik, Volume 1 (1): 1-20

Wirutomo, Paulus. 2003. Pokok-Pokok Pikiran dalam Sosiologi. Jakarta: Grafindo Persada.

\section{Sumber lain (laman internet):}

BPKP Propinsi NTB. 2017. "Mandalika Punya Kita", Artikel. Majalah Exotica Senggigi. (http://www.bpkp.go.id/public/upload/uni t/ntb/files/exo2018.pdf) Diakses 10 April 2017).

KBBI Daring. Kamus Besar Bahasa Indonesia. Pencarian kata: Wisata dan Halal. (https://kbbi.kemdikbud.go.id/) Diakses 10 April 2017). 